\title{
Wake Up Sleepy Head: Sleep Can Be Dangerous
}

\author{
Neil S. Cherniack \\ New Jersey Medical School, Newark, N.J., USA
}

In this issue of Respiration, Trakada et al. [1] report on nocturnal elevations of endothelin-1 (ET-1) in patients with COPD whose blood is well saturated awake but who desaturate during sleep [1]. It is already known that levels of ET-1, a potent vasoconstricting peptide can be elevated in COPD [2], but Trakada et al. found that levels are even higher in sleep desaturators during the day than in nondesaturators. ET-1 was also greater on awakening in sleep desaturators, and there was a strong correlation between ET-1 levels during the day and minimum levels of arterial $\mathrm{O}_{2}$ at night.

ET-1 is a member of a family of 21 -amino-acid peptides $[2,3]$. It is formed by a gene located on chromosome 6 whose activation leads to the formation of a 208-aminoacid prepo-endothelin peptide which is cleaved by the enzyme furin convertase to a 38 -amino-acid endothelin peptide (big endothelin) and subsequently mainly by endothelin converting enzyme to the 21-amino-acid form that circulates in the plasma $[2,3]$.

ET-1 binds to two different kinds of receptors, $\mathrm{ET}_{\mathrm{A}}$ and $\mathrm{ET}_{\mathrm{B}} \cdot \mathrm{ET}_{\mathrm{A}}$ is found on smooth muscle cells and mediates vasoconstriction $[2,3]$. The $\mathrm{ET}_{\mathrm{A}}$ receptor is coupled to a $G_{i}$ protein and leads via the formation of phospholipase $\mathrm{C}$ and inositol triphosphate to an increase in intracellular calcium and ultimately to vasoconstriction. $\mathrm{ET}_{\mathrm{B}}$ receptors are found both in the endothelium $\left(\mathrm{ET}_{\mathrm{B}-2}\right)$ and in smooth muscle $\left(\mathrm{ET}_{\mathrm{B}-1)}\right) . \mathrm{ET}_{\mathrm{B}-1}$ receptors produce relaxation and $\mathrm{ET}_{\mathrm{B}-2}$ constriction. Blocking agents tried experimentally in humans which block both $\mathrm{ET}_{\mathrm{A}}$ and $\mathrm{ET}_{\mathrm{B}}$ receptors produce vasodilatation [4].

\section{KARGER}

Fax +4161306 1234

E-Mail karger@karger.ch

www.karger.com

(c) 2001 S. Karger AG, Basel

0025-7931/01/0682-0129\$17.50/0

Accessible online at:

www. karger.com/journals/res
}

ET-1 is elevated in primary and secondary pulmonary hypertension [2,5] and in a number of diseases including some cases of systemic hypertension (particularly among Afro-Americans), renal ischemia and congestive heart failure. In addition to its smooth muscle effects, ET-1 is a mitogen and a leukocyte attractant, and promotes the formation of several growth factors like vascular endothelial growth factor.

ET-1 is elevated by hypoxia which may act both to increase ET-1 expression by increasing the binding of transcription factors such as AP-1 to the ET- 1 gene and by increasing the activity of endothelin-converting enzymes $[2,3,7]$. ET- 1 is believed to be one of the factors mediating pulmonary hypertension (at altitude and with congestive heart failure for example, and it has been implicated in cor pulmonale) [2]. The study reported in this issue finds that even the transient hypoxia that occurs during sleep can elevate ET-1 and possibly increase tendencies to pulmonary hypertension and right heart failure.

It is of interest that hyperoxia also increases ET-1 levels [6]. In this case, the action is believed to be mediated by the formation of reactive oxygen species. Intermittent hypoxia in many instances has been shown to produce the same effects as chronic hypoxia and at times even more rapidly. It may be that repetitive episodes of hypoxia and normoxia cause oxygen radical formation similarly to ischemia followed by reperfusion. If this is true, it is possible that adverse effects depend on the clustering of hypoxic/normoxic episodes and not just on the duration of hypoxia [7].
Neil S. Cherniack, MD

Office of the Dean, UMDNJ - New Jersey Medical School

185 South Orange Avenue

Newark, NJ 07103-2714 (USA)

Tel. +1 973972 7937, Fax +19739723585 
While ET-1 probably is a significant factor influencing the occurrence of pulmonary hypertension, many other factors are also involved. Besides vasoconstrictors like ET-1, vasodilators like nitric oxide (NO) and prostacyclin are produced by the lung (in the endothelium). Hypoxia increases NO as well as ET-1. The functional effects of rises in ET-1 probably depend on the magnitude of simultaneous changes in NO and prostacyclin [2].
In the meantime, the new study supports the need for further examinations of sleep in patients with chronic lung disease which may provide clues leading to new methods for slowing the effects of the disease on the cardiovascular system.

\section{References}

1 Trakada G, Marangos M, Spiropoulos K: Mechanisms of endothelin-1 elevation in chronic obstructive pulmonary disease patients with nocturnal oxyhemoglobin desaturation. Respiration 2001;68:134-139.

2 Chen Y-F, Oparil S: Endothelial dysfunction in the pulmonary vascular bed. Am J Med Sci 2000;320:223-232.

3 Lüscher TF, Barton M: Endothelins and endothelin receptor antagonists: Therapeutic considerations for a novel class of cardiovascular drugs. Circulation 2000;102:2434-2440.
4 Fleisch M, Sütsch G, Yan XW, Wenzel RR, Binggeli C, Bianchetti MG, Meier B, Kiowski W, Lüscher TF: Systemic, pulmonary, and renal hemodynamic effects of endothelin $\mathrm{ET}_{\mathrm{A} / \mathrm{B}}-$ Receptor blockade in patients with maintained left ventricular function. J Cardiovasc Pharmacol 2000;36:302-309.

5 Moraes DL, Colucci WS, Givertz MM: Secondary pulmonary hypertension in chronic heart failure: The role of the endothelium in pathophysiology and management. Circulation 2000;102:1718-1723.
6 Jankov RP, Luo XP, Cabacungan J, Belcastro R, Frndova H, Lye SJ, Tanswell AK: Endothelin-1 and $\mathrm{O}_{2}$ mediated pulmonary hypertension in neonatal rats: A role for products of lipid peroxidation. Pediatr Res 2000;48:289298.

7 Voelkel NF, Tuder RM: Hypoxia-induced pulmonary vascular remodeling: A model for what human disease? J Clin Invest 2000;106:733738. 